\title{
Rancang Bangun Aplikasi Pembuatan Presentasi Berbasis Web Menggunakan HTML5
}

\author{
Prima Astiadi ${ }^{1}$, Oesman Hendra Kelana ${ }^{2}$ \\ ${ }^{1,2}$ Program Studi Teknik Informatika, Universitas Ma Chung \\ Jl. Villa Puncak Tidar N-01, Malang 65151 \\ Email: primaastiadi@gmail.com, ${ }^{2}$ oesman.hendra@machung.ac.id
}

\begin{abstract}
The goal of this thesis is to simplify the process of creating a web-based presentation and to provide solutions for compatibility problems in a standalone application. HTML5 is the latest web technology which is constantly developed and will be the successor of the previous HTML generation. This service for creating web-based presentation will make use of HTML5 features and JavaScript to deliver a user-friendly web-based application, with a concern in receiving text as its input and maintening it into a web-based presentation.This web-based presentation-making application, namely Slides5, provides an interface for creating a presentation with some features such as the addition and removal of slides, changing the look and layout of slides, as well as save and download the presentation file. Through several testings, Slides5 has succeeded in creating web-based presentation materials without the need of programming. In addition, Slides5 provides a feature to save the presentation as a HTML file so that the presentation can be simply concucted by using any web browser.
\end{abstract}

Keywords: web-based presentation, HTML5, Slides5

\begin{abstract}
Abstrak. Tujuan dari penelitian ini adalah menyederhanakan proses pembuatan presentasi berbasis webdan memberikan solusi atas permasalahan kompatibilitas pada aplikasi mandiri.HTML5 merupakan teknologi web terbaru yang terus dikembangkan dan akan segera menjadi penerus dari generasi HTML sebelumnya. Layanan pembuatan presentasi berbasis web yang dimaksud akan memanfaatkan fitur HTML5 dan JavaScript untuk menghadirkan aplikasi berbasis web yang ramah pengguna, dengan menitikberatkan dalam menerima masukan berupa teks dan mengelolanya menjadi presentasi berbasis web.Aplikasi pembuatan presentasi berbasis web yang bernama Slides5 ini menyediakan antarmuka pembuatan presentasi dengan fitur-fitur seperti penambahan dan penghapusan slide, pengubahan tampilan dan tata letak slide, serta penyimpanan dan pengunduhan berkas presentasi. Melalui sejumlah uji coba, Slides5 telah berhasil dalam membuat materi presentasi berbasis web tanpa harus melakukan pemrograman. Selain itu, Slides5 menyediakan fitur penyimpanan presentasi ke dalam bentuk berkas HTML sehingga presentasi dapat dilakukan hanya dengan menggunakan peramban web saja.
\end{abstract}

Kata Kunci: presentasi berbasis web, HTML5, Slides5

\section{Pendahuluan}

\subsection{Latar Belakang}

Dewasa ini, aktivitas presentasi menjadi sebuah kegiatan yang banyak dilakukan oleh berbagai kalangan dengan tujuan edukasi, persuasi maupun pemberian informasi. Materi presentasi pada umumnya dibuat dengan penyajian yang begitu menarik yang mencakup hal-hal yang akan dijelaskan oleh pemberi materi.

Kehadiran aplikasi standalone seperti Microsoft PowerPoint, Libre Office Impress, ataupun Key Note pada sistem operasi yang berbeda sangat membantu dalam menyajikan presentasi yang menarik serta interaktif. Namun pada kenyataannya, setiap aplikasi tersebut memiliki keunikan masing-masing, terutama jenis ekstensi berkas yang berbeda untuk tiap-tiap aplikasi. Hal ini menimbulkan masalah kompatibilitas yang menyebabkan berkas yang tercipta dari sebuah aplikasi pembuat presentasi hanya dapat dibuka dan ditampilkan dengan sempurna oleh aplikasi pembuat presentasi itu sendiri. Sebagai contoh, presentasi yang dibuat dengan menggunakan PowerPoint hanya dapat ditampilkan dengan sempurna apabila menggunakan 
PowerPoint itu sendiri. Permasalahan tersebut juga berlaku pada presentasi yang dibuat dengan aplikasi berbeda. Beberapa aplikasi pembuat presentasi telah memberikan fitur untuk menyimpan berkas ke dalam format yang dapat dimengerti oleh aplikasi pembuat presentasi sejenis, namun hal tersebut masih belum dapat menghindarkan perubahan format yang terjadi saat berkas presentasi tersebut dibuka menggunakan aplikasi lain.

Kehadiran layanan berbasis web seperti Google Docs membawa alternatif solusi dengan kemampuannya untuk menyajikan konten presentasi secara online. Dengan terlebih dahulu terkoneksi dengan internet, seseorang dapat menampilkan berkas presentasi yang telah dibuat sebelumnya menggunakan Google Docs. Google Docs juga memberikan fitur untuk mengunduh berkas yang telah dibuat, namun fitur penyimpanan berkas masih terbatas pada ekstensi PDF, PPT, TXT dan format berupa gambar seperti JPEG, PNG, dan SVG. Tentu saja permasalahan kompatibilitas masih belum dapat dihilangkan sepenuhnya.

Berdasarkan permasalahan di atas, tercipta ide untuk menyediakan sebuah layanan pembuatan presentasi berbasis web yang dapat dengan mudah digunakan oleh semua kalangan melalui peramban web yang dapat ditemui di berbagai jenis sistem operasi. Nantinya, peramban web digunakan sebagai media untuk membuat dan menayangkan presentasi yang telah dibuat. Selain itu, layanan ini akan menciptakan berkas presentasi dalam format berkas HTML (HyperText Markup Language) yang dapat diterjemahkan oleh mayoritas peramban web yang ada. Kehadiran layanan pembuatan presentasi berbasis web ini diharapkan dapat menjadi sebuah alternatif untuk dapat mengatasi masalah kompatibilitas dan penyajian presentasi yang pada umumnya ditemui di aplikasi-aplikasi standalone untuk membuat presentasi yang banyak beredar.

\subsection{Perumusan Masalah}

Berikut adalah beberapa pokok permasalahan yang ada: (1) Bagaimana membuat layanan presentasi melalui web yang dapat membantu pengguna untuk membuat presentasi tanpa harus berurusan dengan kode-kode pemrograman terkait. (2) Bagaimana memberikan hasil layanan yang dapat mengatasi permasalahan kompatibilitas ekstensi berkas presentasi yang pada umumnya ditemukan pada aplikasi standalone untuk membuat presentasi.

\subsection{Tujuan Penelitian}

Tujuan umum dari pembuatan layanan ini adalah untuk menyediakan aplikasi berbasis web yang dapat berfungsi sebagai alat bantu untuk membuat presentasi. Sedangkan, tujuan khusus dari layanan yang ingin dikembangkan adalah sebagai berikut: (1) Menyediakan layanan pembuatan presentasi berbasis web yang dapat diterima oleh semua kalangan pengguna internet, baik pengguna dengan latar belakang IT maupun bukan. (2) Memberikan alternatif solusi presentasi melalui web untuk mengatasi permasalahan kompatibilitas yang ditemui pada aplikasi standalone.

\section{Tinjauan Pustaka}

\subsection{HTML5}

HTML adalah sebuah bahasa markup yang menjadi pusat dari struktur desain sebuah website (Powell, 2010). Kode yang berada di belakang setiap tampilan halaman website ini memungkinkan pengembang website untuk menciptakan tampilan dari sebuah halaman website sesuai dengan yang diinginkannya. Dikembangkan pertama kali oleh Tim Berners-Lee pada tahun 1989, HTML menjadi bahasa markup yang terus berkembang hingga saat ini (David, 2010). Salah satu hal yang menyebabkan HTML menjadi bahasa yang sukses dalam perkembangannya adalah konsep sederhana akan penggunaan tag yang menandai awal maupun akhir dari sebuah bagian. Hingga saat ini, HTML4 menjadi bahasa markup standar yang digunakan untuk mengembangkan website.

Pada tahun 2007, sebuah tim yang bernama Web Standards Project memulai untuk membuat generasi penerus dari HTML, yaitu HTML generasi ke 5 (David, 2010). HTML5 menyertakan pendefinisian ulang dari element markup yang ada dan pendefinisian elemen- 
elemen baru yang memungkinkan para pendesain web untuk lebih ekspresif dalam semantik dari markup-nya (Glodstein, 2011). Dengan tujuan memberikan standar yang memungkinkan untuk menjalankan aplikasi dalam sebuah peramban web, HTML5 memperkenalkan beberapa fitur-fitur baru, beberapa diantaranya adalah: Elemen HTML baru, Geolocation APIs (Application Programming Interface), Localdata APIs, Forms 2.0., dukungan untuk video dan audio, CSS3, pencitraan gambar 2 dimensi dan 3 dimensi, JavaScript 2.0.

HTML5 kompatibel dengan versi-versi sebelumnya. Semua spesifikasi fitur HTML4 ada dalam HTML5, bahkan mengalami perubahan dan pengembangan (Clark, 2012). Perbedaan utama HTML5 dan HTML 4 adalah adanya tambahan API (Application Programming Interfaces) Javascript dalam spesifikasinya. Tambahan API ini memampukan adanya interaksi dengan elemen multimedia di dalam peramban (Devlin, 2012). HTML5 juga mengembangkan antarmuka pengguna (user interface), kemampuan akses (accessability), efek visual (visual effect), multimedia yang semakin tidak bergantung pada plug-ins, dan web sockets yang menjadikan koneksi dengan web server menjadi lebih persisten (Hogan, 2013).

Seperti pendahulunya, HTML5 dirancang sebagai bahasa yang cross-platform, penggunaannya tidak didasarkan pada platform dimana HTML5 itu sendiri berjalan. Yang dibutuhkan untuk memanfaatkan fitur-fiturnya hanyalah sebuah peramban web yang modern. Secara umum, semua peramban web telah mengadopsi HTML4 sebagai standar. Namun, HTML5 mulai banyak diaplikasikan pada banyak website di internet. Hal itu diikuti oleh peramban web ternama seperti Chrome, Opera, Mozilla Firefox, Safari, dan Internet Explorer yang memberikan dukungan untuk HTML5 (Sanders, 2011). Hal ini menunjukkan bahwa HTML5 akan segera menjadi standar sebagai bahasa markup untuk web.

Gambar 1 mengambarkan aplikasi HTML5 beserta komponen-komponennya. Bagian atas tertera aplikasi-aplikasi yang ada dalam HTML5, yakni HTML, CSS, dan Javascript, dimana aplikasi-aplikasi ini dibangun berdasarkan komponen-komponen yang ada di bagian bawah, yakni JavaScript API, HTML5 markup, dan CSS3 (Gustafson, 2013).

Ada dua organisasi yang membuat spesifikasi HTML5, yakni W3C (World Wide Web Consortium) dan WHATWG (Web Hypertext Application Technology Working Group). HTML5 pada mulanya ditulis oleh WHATWG, yang didirikan pada tahun 2003, dengan anggota-anggotanya yang terdiri dari: Apple, Mozilla, dan Opera. Pada tahun 2006, W3C membentuk sendiri kelompok kerja untuk HTML5 berdasarkan atas kerja yang telah dilakukan WHATWG. Kedua lembaga ini menghasilkan spesifikasi yang tidak terlalu jauh berbeda (Robbins, 2013).

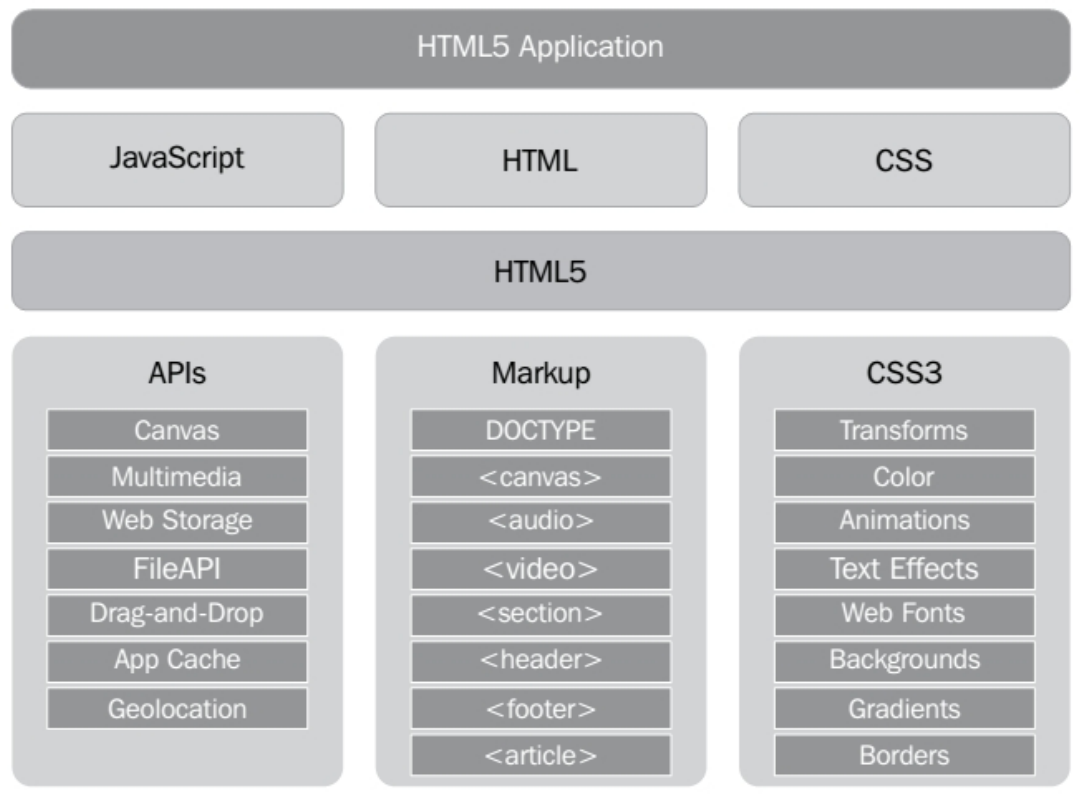

Gambar 1. Aplikasi dan Komponen HTML5 


\subsubsection{HTML5 contentEditable}

HTML5 contentEditable adalah sebuah fitur yang memungkinkan pengguna untuk dapat melakukan perubahan konten secara langsung pada sisi antarmuka sebuah website. Kode 1 menunjukkan penggunaan atribut contentEditable dalam sebuah struktur DOM (Document Object Model) yang mengubah elemen section menjadi area penyuntingan. Dengan memberikan nilai true pada atribut tersebut, maka peramban web akan memberikan izin untuk melakukan perubahan konten pada area yang dimaksud. Sebaliknya nilai false, merupakan nilai default pada atribut ini, menonaktifkan kemampuan untuk melakukan proses penyuntingan konten.

Kode 1. Penggunaan Atribut contentEditable dalam Sebuah Struktur DOM

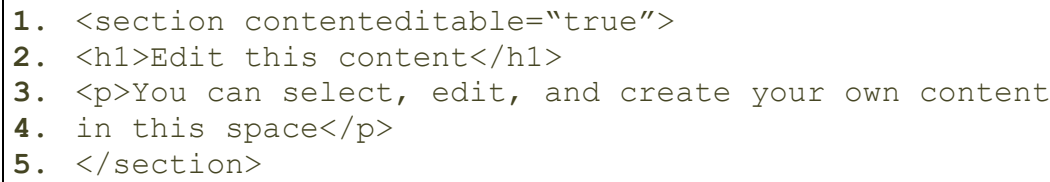

\subsubsection{HTML5 Web Storage}

Fitur ini memampukan sebuah aplikasi memiliki database lokal yang berada di dalam peramban web yang digunakan, dengan kemampuan penyimpanan data yang lebih besar dibandingkan dengan kemampuan penyimpanan cookies. Kapasitas penyimpanan yang dimiliki oleh web storage bisa berbeda-beda, tergantung pada peramban web yang digunakan.

Keuntungan yang didapat dengan kehadiran database lokal ini yaitu memungkinkan aplikasi berbasis web untuk menyimpan data secara lokal dan dapat memanipulasi data tersebut tanpa harus terhubung dengan internet. Fitur ini telah banyak diimplementasikan oleh beberapa website seperti Google's Gmail, Calendar, dan Docs. HTML5 web storage dibagi menjadi dua macam yaitu localStorage dan sessionStorage. Data yang disimpan pada sessionStorage memiliki masa waktu dan akan terhapus bersamaan dengan berakhirnya session dari pengguna. Sedangkan data yang disimpan dalam localStorage akan tetap tersimpan sampai data tersebut dihapus atau diganti dengan data yang lebih baru.

\subsection{Framework}

Dalam pengembangan sebuah website, dibutuhkan aktivitas pemrograman yang banyak melibatkan penggunaan kode-kode maupun operasi yang berulang-ulang. Pada umumnya, penataan kode pemrograman untuk manipulasi data, penggunaan logika, dan tampilan menjadi satu dalam sebuah halaman atau berkas. Hal ini cukup merepotkan ketika pengembang harus melakukan perubahan pada program, dan lebih merepotkan lagi apabila pengembang terdiri dari beberapa orang yang tergabung dalam sebuah tim kerja. Tak jarang, hal ini disadari saat kode program telah berkembang menjadi begitu kompleks. Oleh karena itu, diperlukan sebuah kerangka kerja yang dapat menyederhanakan pengkodean program dan meminimalkan pengulangan kode-kode yang tidak diperlukan. Kerangka kerja inilah yang disebut dengan framework.

Secara umum, framework dapat diartikan sebagai alat yang dapat digunakan untuk membantu seseorang dalam melakukan sebuah pekerjaan. Definisi framework secara khusus adalah sebuah susunan atau rangkaian kerja yang tetap dan dibuat sedemikian rupa yang kemudian dapat digunakan kembali dalam sebuah aktifitas kerja yang lain namun tetap dalam satu area kerja yang sama dengan rangkaian kerja sebelumnya. Web framework memiliki definisi kumpulan sebuah maupun banyak modul-modul dalam bentuk class library yang dapat digunakan kembali untuk membentuk sebuah aplikasi web yang lebih besar dengan memanfaatkan modul-modul class library tersebut.

Dalam penggunaan framework, masih dibutuhkan penulisan-penulisan kode pemrograman yang disesuaikan dengan lingkungan framework yang digunakan. Framework menyediakan lingkungan pengembangan yang terstruktur, serta menyediakan berbagai macam fungsi siap pakai yang dapat digunakan dalam pengembangan website. Selain itu, tersedianya 
kerangka pola kerja terstandar akan mempermudah pengembang website untuk memahami kode pemrograman yang ditulis oleh rekan lain saat bekerja di dalam sebuah tim kerja.

Website yang dinamis, seperti halnya software aplikasi, terdiri dari tiga buah komponen: data, presentation, dan logic. Dalam istilah framework web, komponen ini dikenal dengan istilah: model, view, dan controller. Ketika membuat website yang sederhana, ketiga komponen ini bercampur dan tidak menjadi masalah. Tetapi ketika membuat website besar dan kompleks, bercampurnya ketiga komponen ini akan menjadi masalah karena akan menimbulkan kesulitan dalam penanganannya. Untuk menangani masalah ini, ketiga komponen tersebut harus dipisahkan dalam bagian-bagian yang berbeda, dan penulisan kode program juga harus bersifat terpisah (loosely). Dengan menghilangkan saling ketergantungan antar komponen maka website yang dibuat akan lebih mudah dalam penanganannya (manageable), pengujian (testable), dan pengembangan (scalable) (Gilmore, 2011).

Ada banyak framework yang telah beredar, beberapa diantaranya yang cukup populer adalah CodeIgniter, YII Framework, Kohana, Ruby on Rails, dan CakePHP. Tentunya masingmasing framework memiliki standar pola kerja yang berbeda-beda, dengan masing-masing kelebihan dan kekurangannya.

\subsection{FuelPHP}

FuelPHP merupakan sebuah PHP web framework yang masih tergolong baru, sederhana, fleksibel serta didukung oleh komunitas yang dikembangkan berdasar ide-ide terbaik dari PHP framework lainnya. Pengembangannya dimulai sejak tahun 2010 oleh Dan Horrigan yang tidak lama kemudian berkembang dengan masuknya Phil Sturgeon, Jelmer Schreuder, dan Harro Verton ke dalam tim pengembang. Tim tersebut telah memiliki pengalaman mengenai PHP selama kurang lebih satu dekade, dan telah terlibat dalam beberapa proyek Open-Source seperti CodeIgniter, PyroCMS, ExiteCMS, dan DataMapper ORM.

Filosofi dari FuelPHP yaitu mengambil pendekatan yang berbeda dengan kebanyakan framework dan berusaha untuk menjadi framework yang didukung oleh komunitas. FuelPHP menjadi sebuah MVC (Model-View-Controller) framework yang didesain dengan baik untuk memiliki dukungan penuh untuk HMVC (Hierarchial Model-View-Controller) sebagai bagian dari arsitekturnya. Tidak hanya itu, FuelPHP juga menambahkan ViewModel yang merupakan sebuah class yang berisikan logika yang membantu dalam membangun View itu sendiri. Selain itu, FuelPHP juga memberikan perhatian terhadap keamanan terhadap website untuk mencegah penyerangan-penyerangan yang mungkin dilakukan oleh pihak-pihak yang tidak diketahui seperti XSS attack, SQL injection, dan lain sebagainya. Fitur lain yang didukung oleh FuelPHP: (1) Class yang bersifat modular dan extendsible. (2) Oil, sebagai utilitas baris perintah yang dapat mempercepat pengembangan website dengan kemampuannya yang dapat membantu dalam hal pengujian maupun pencarian kesalahan dalam pengkodean. (3) Object Relational Mapper (ORM) dan Active Record yang membantu dalam melakukan operasi pada basis data.

\section{Analisis dan Perancangan Sistem}

\subsection{Desain Sistem}

Gambar 2 adalah gambaran sitemap dari aplikasi pembuatan presentasi berbasis web. Pada tahapan awal, pengguna mengunjungi website yang dimaksud. Pada halaman utama, pengguna diberikan pilihan secara langsung untuk dapat memulai aktivitas pembuatan presentasi. Proses pertama yang dilalui adalah pemilihan tema presentasi yang akan dibuat. Sistem memberikan beberapa pilihan tema untuk dapat dipilih oleh pengguna.

Proses berikutnya adalah aktivitas pembuatan presentasi itu sendiri. Pada tahapan awal, sistem akan mengecek apakah pengguna memiliki data presentasi lama yang pernah dibuat sebelumnya. Jika pengguna memiliki data tersebut, maka akan diberikan pilihan untuk dapat memuat kembali data presentasi yang lama. Mengenai proses penyimpanan data presentasi akan dijelaskan pada bagian selanjutnya. Di halaman pembuatan presentasi, pengguna akan dibantu oleh editor untuk dapat melakukan pemformatan pada teks yang menjadi masukan. Selain itu, 
disediakan juga beberapa fungsi untuk memanipulasi slide seperti menambah slide presentasi, menghapus slide presentasi, dan lain sebagainya.

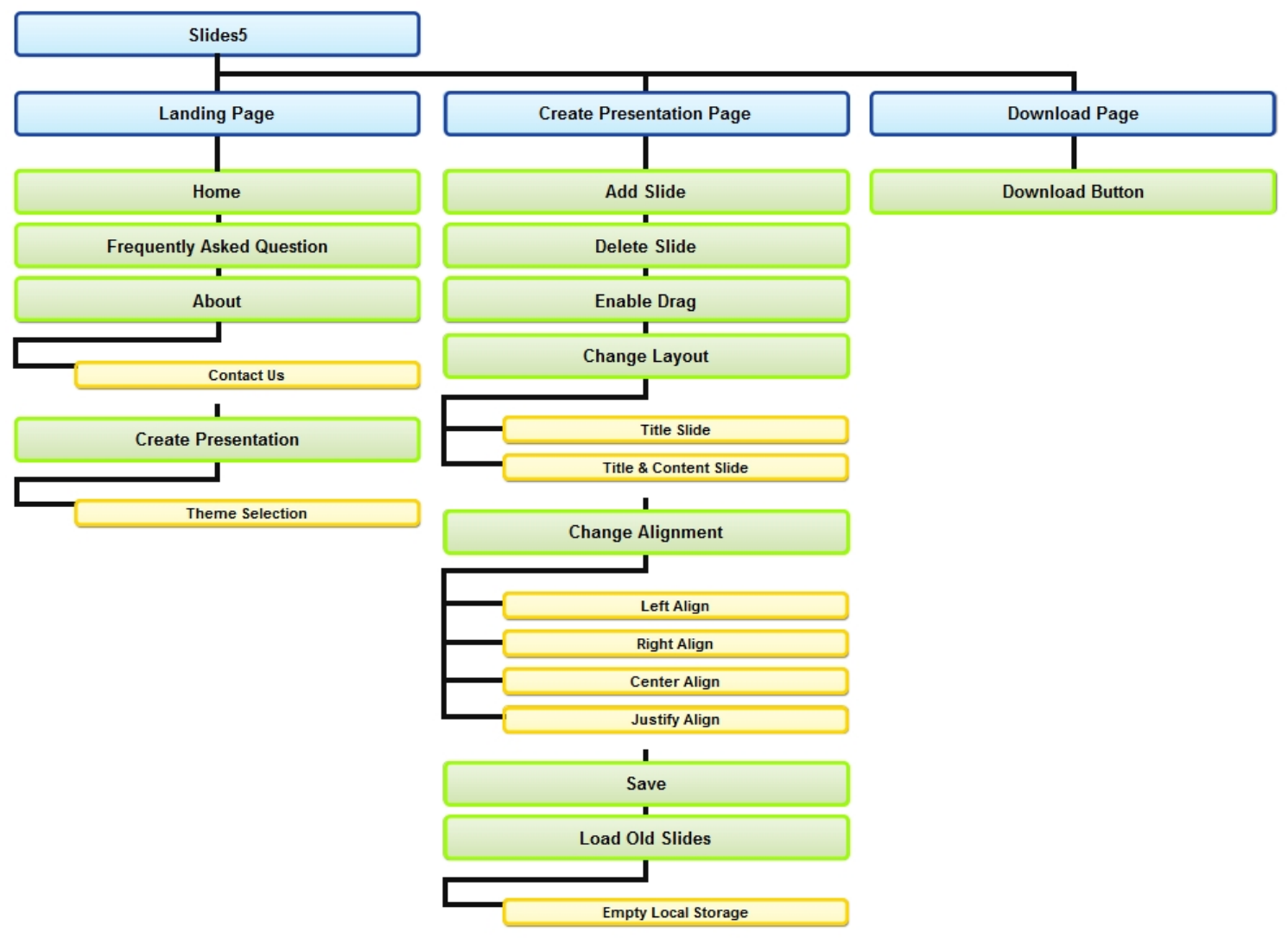

Gambar 2. Sitemap Slides5

Setelah pengguna selesai dalam pembuatan presentasi yang diinginkan, maka pengguna dapat menyimpan presentasi yang dibuat dengan melakukan klik pada tombol save (process). Dengan mengakses tombol save, maka sistem akan memberikan kotak dialog untuk dapat memasukkan judul dari presentasi. Judul presentasi yang dimasukkan oleh pengguna nantinya akan menjadi title dari halaman presentasi yang dimaksud. Apabila judul dari presentasi telah dimasukkan, berikutnya sistem akan melakukan dua tahapan. Pertama, sistem akan mencatat isi presentasi dan disimpan dalam localStorage apabila peramban web yang digunakan oleh pengguna mendukung penggunaan localStorage. Kedua, sistem akan melakukan proses pencatatan isi dari presentasi yang dibuat oleh pengguna.

Setelah proses pencatatan selesai, maka presentasi telah siap untuk diunduh dan sistem akan melakukan redirect ke halaman unduh. Pengguna juga dapat mengunduh presentasi yang telah selesai diproses sehingga praktis untuk dibawa melalui alat penyimpanan data portabel seperti thumbdrive, compact-disc, dan lain sebagainya.

\subsection{Desain Program}

\subsubsection{Pemilihan Tema Presentasi}

Pada tahapan awal, pengguna diharuskan memilih tema yang akan digunakan untuk presentasi yang akan dibuat. Setelah pengguna memilih tema, maka sistem akan melakukan proses berikutnya untuk menciptakan presentasi baru.

\subsubsection{Pembuatan Presentasi}

Proses berikutnya adalah proses pembuatan presentasi itu sendiri. Pada halaman pembuatan presentasi, pengguna akan dibantu oleh beberapa fungsi JavaScript pendukung 
pembuatan presentasi. Pemanfaatan fungsi dalam bentuk JavaScript yang bersifat client-side akan sangat membantu dalam proses pembuatan presentasi, sehingga meminimalkan lalu lintas antara pengguna dan server. Beberapa fungsi pendukung itu antara lain: add slide, delete slide, change layout, change alignment, enable dragging, save, download, load old slide.

\subsection{Implementasi dan Pengujian}

Pada tahapan awal, akan dilakukan pembuatan program per bagian kecil. Seperti yang telah dijelaskan sebelumnya, FuelPHP akan digunakan sebagai framework dalam pengembangan aplikasi presentasi berbasis web. Dengan pengembangan per bagian kecil, diharapkan dapat mempercepat pengembangan dengan berfokus pada masing-masing bagian tersebut. Selain melakukan pengembangan, juga dilakukan pengujian untuk masing-masing komponen yang telah selesai dibuat. Hal ini dilakukan untuk menguji apakah fungsi dari komponen tersebut sudah dapat berjalan dengan baik dan benar.

Tahapan berikutnya yaitu melakukan proses integrasi untuk masing-masing komponen yang telah dibuat dan diuji sebelumnya. Di samping itu, pengujian juga dilakukan terhadap aplikasi secara keseluruhan untuk menguji kembali fungsi dari masing-masing komponen. Pengujian juga mencakup bagaimana interaksi antara pengguna dan sistem. Semuanya dilakukan untuk mendapatkan hasil yang maksimal dengan meminimalkan kesalahan-kesalahan maupun hal-hal yang kurang berguna.

Setelah penggabungan dan pengecekan aplikasi secara utuh telah selesai, maka akan dilakukan optimisasi dengan menggunakan Smart Optimizer. Seperti yang telah dijelaskan sebelumnya, Smart Optimizer berguna dalam melakukan kompresi berkas-berkas web sebelum dikirim kepada pengguna agar beban pengunduhan halaman dapat dioptimalkan. Hal ini sangat berguna khususnya di halaman pembuatan presentasi karena ada cukup banyak berkas web yang harus diunduh dalam sekali waktu.

\subsection{Operasi dan Pemeliharaan}

Tahapan terakhir yaitu tahap pengoperasian dan pemeliharaan terhadap aplikasi berbasis web yang dibuat. Pengoperasian dilakukan dengan melakukan mengunggah berkas-berkas website dari posisi lokal ke server web. Di samping itu, pemeliharaan juga dilakukan untuk mengetahui kinerja sistem secara utuh.

Salah satu pemeliharaan yang dilakukan dalam website ini adalah penghapusan berkasberkas presentasi yang sudah tidak terpakai. Setiap kali pengguna membuat presentasi, akan tercipta satu berkas presentasi baru di server. Hal ini akan menyebabkan penumpukan berkasberkas presentasi seiring dengan semakin banyaknya pengguna yang memanfaatkan website ini. Oleh karena itu dibutuhkan sebuah fungsi yang dapat mengatur penghapusan berkas-berkas presentasi dengan batas tertentu. Website akan menyimpan semua file presentasi yang pernah dibuat dalam kurun waktu 30 hari. Berkas presentasi yang memiliki usia lebih dari 30 hari terhitung sejak tanggal pembuatan akan dihapus dari server.

Fungsi penghapusan berkas ini nantinya akan diset dengan menggunakan cron job sehingga akan berjalan dengan sendirinya tanpa perlu secara manual mengakses fungsi tersebut. Selain itu, tidak menutup kemungkinan untuk dilakukan pengembangan ke arah yang lebih lanjut untuk membuat aplikasi terkait dapat berguna serta berfungsi dengan lebih baik lagi.

\section{Hasil dan Pembahasan}

Pada bagian ini, akan dijelaskan hasil dari aplikasi yang telah dibuat beserta dengan beberapa gambar untuk mendukung penjelasan yang ada. Pengujian dapat dilakukan langsung dengan mengakses alamat http://slides5.com/.

\subsection{Front End}

Front end dari website Slides5 (Gambar 3) menerapkan prinsip single page website. Single page website menjadi sebuah cara penyajian yang baik dengan mengumpulkan semua informasi yang berguna mengenai website terkait dalam satu halaman utuh. Hal ini tentunya 
memberikan keuntungan tersendiri bagi pengunjung yang mengakses website tersebut karena semua kode yang dibutuhkan seperti HTML, JavaScript, dan CSS didapatkan dengan sekali unduh. Di samping itu, hal ini juga memudahkan pemrogram dalam melakukan pengembangan website sehingga tidak perlu menciptakan halaman view yang terlalu banyak. Setelah semua komponen yang dibutuhkan telah siap, maka pengguna akan mendapatkan akses ke semua informasi dasar yang ada di website terkait. Halaman utama dari Slides5 dibagi menjadi tiga bagian kecil yaitu frequently asked question, about, dan create presentation.

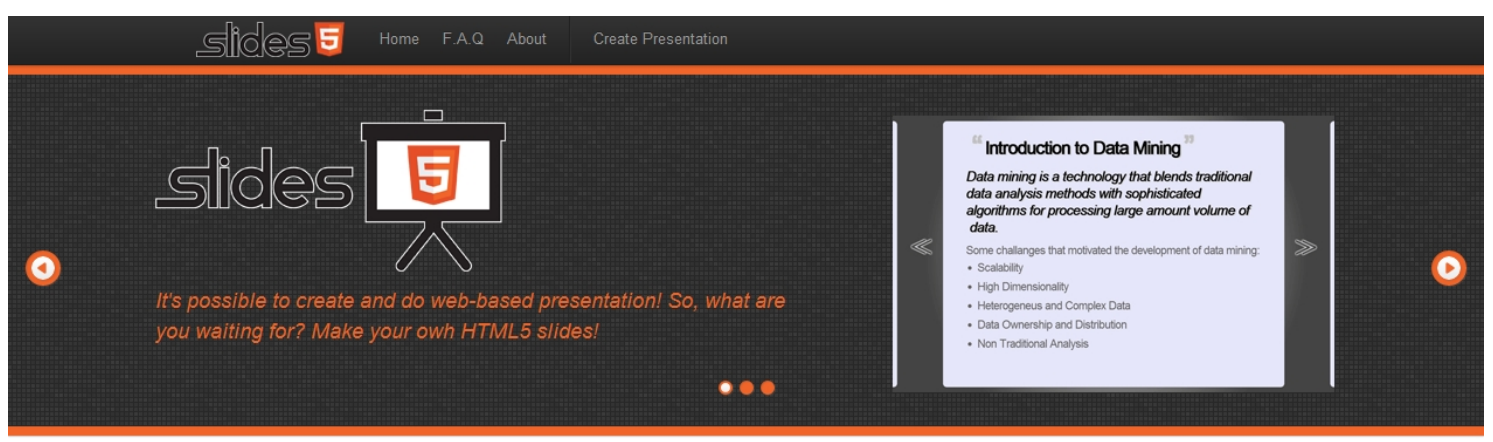

F.A.Q frequently asked question

What is Slides 5 ?

Slides 5 is a simple project which help everyone to make a web-based presentation that use HTML 5 technology

Why HTML5?

\section{Gambar 3. Halaman Beranda Slides5}

\subsubsection{Frequently Asked Question}

Bagian ini (Gambar 4) berisi tentang segala informasi dasar yang mungkin dibutuhkan oleh pengguna saat pertama kali mengunjungi website ini. Selain itu bagian ini juga berisi informasi yang harus diperhatikan oleh pengguna seperti informasi mengenai peramban web yang didukung, ekstensi dari berkas file yang diciptakan, dan lain sebagainya.

\section{Slides 5 Home F.AQ About Create Presentation}

What is Slides 5 ?

Slides 5 is a simple project which help everyone to make a web-based presentation that use HTML5 technology

\section{Why HTML5?}

HTML5 is the fifth generation of HTML for web which is widely supported today by modern internet browser and better structured compared to its predecessor

Why HTML5 presentation?

All you need to have is a browser that support HTML5, and you can make and do your presentation. No need for additional software or add-ons.

Does my browser support HTML5?

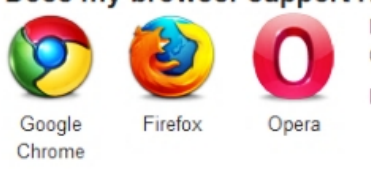

Nowadays many web browser, especially some modern browser, support HTML5. Currently tested browsers are Google Chrome, Firefox and Opera Web Browser

If you want to know how well your browser support HTML5, check it here: html5test.com

Then, how to start?

Simple. Create, type your content, save, and download it. No coding required!

About the file extension?

It's a HTML (.html) file. Just double click and you can launch and do your presentation via your web browser!

Want to give it a try?

Start creating your own presentation then

Gambar 4. Bagian Frequently Asked Question pada Slides5 


\subsubsection{About}

Bagian ini (Gambar 5) berisi penjelasan singkat seputar Slides5 seperti tujuan, dan kegunaan dari website terkait. Selain itu bagian ini juga berisi informasi berupa alamat email yang dapat dituju apabila pengguna memiliki pertanyaan mengenai website terkait.

\section{Slides 5 Home F.AQ About Create Presentation}

Nowadays, there are so many options for creating web-presentation, and some of them requires one to understand how to make it through coding process. Of course it'll be faster to make web-based presentation if someone has an experience in coding, and sometimes it takes a lot of time to understand about it. What if someone don't have enough time to learn all of it?

So, here it comes, the Slides 5 project. The objectives of this project is to help people making a web-based presentation easier that implements HTML5 and CSS3 technique. Although the feature is limited, it gives a new experience in creating web-based presentation. It is efficient, time saving, and convenient for those who need a quick way to create web-based presentation. Just type, save, and your presentation is ready to be downloaded as a html file. With HTML5-ready browser, you can launch and do your presentation.

Slides 5 is a part of final year project of my studies in Ma Chung University, 2008-2012. The project itself is based on Google HTML 5 slide template, assisted by Aloha editor as the WYSIWYG editor

Slides 5 logo is based on HTML5 Logo by W3C. Design by C's Studio.

\section{Gambar 5. Bagian About pada Slides5}

\subsubsection{Create Presentation}

Bagian ini (Gambar 6) adalah bagian dimana pengguna dapat memulai untuk membuat presentasi. Pada bagian ini, pengguna dihadapkan dengan beberapa pilihan tema yang telah disediakan. Saat website ini dikembangkan, terdapat sembilan buah pilihan tema dan tidak menutup kemungkinan untuk tambahan tema-tema lain di masa mendatang.

Untuk memulai membuat presentasi, pengguna harus memilih salah satu tema yang ada. Setelah pengguna selesai memilih tema yang diinginkan, pengguna dapat melanjutkan ke tahapan berikutnya dengan mengakses tombol proceed yang telah disediakan.

\section{Sildes 5 Home F.A.Q About Create Presentation}

Choose theme

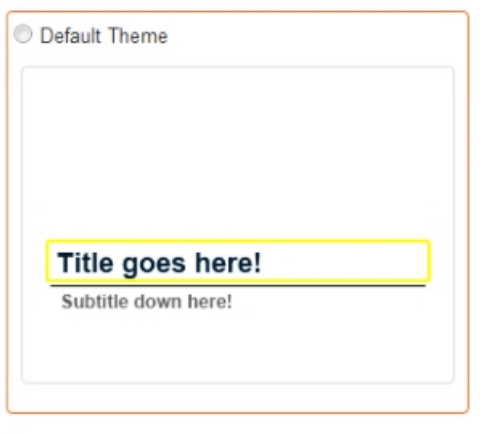

Khaki Theme
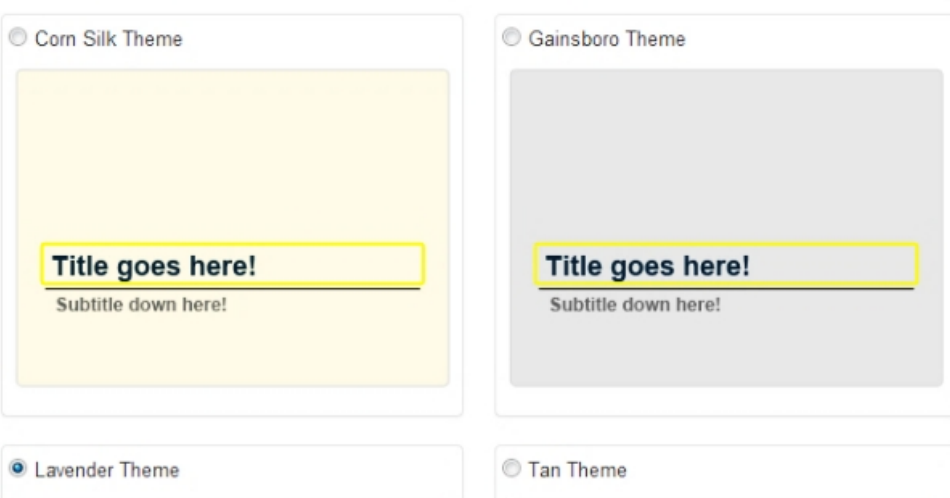

Gambar 6. Bagian Create Presentation pada Slides5

\subsection{Halaman Pembuatan Presentasi}

Halaman ini (Gambar 7) adalah halaman dimana pengguna dapat mulai berinteraksi dengan aplikasi untuk menciptakan presentasi yang diinginkan. Pada halaman ini, pengguna akan bekerja dengan tema presentasi yang telah dipilih pada proses sebelumnya. Berikut adalah tampilan dari halaman pembuatan presentasi.

Seperti yang terlihat pada Gambar 7, halaman pembuatan presentasi ini dapat dibagi menjadi tiga bagian utama, yaitu: (1) Action panel (2) Area penyuntingan (3) Area navigasi. 


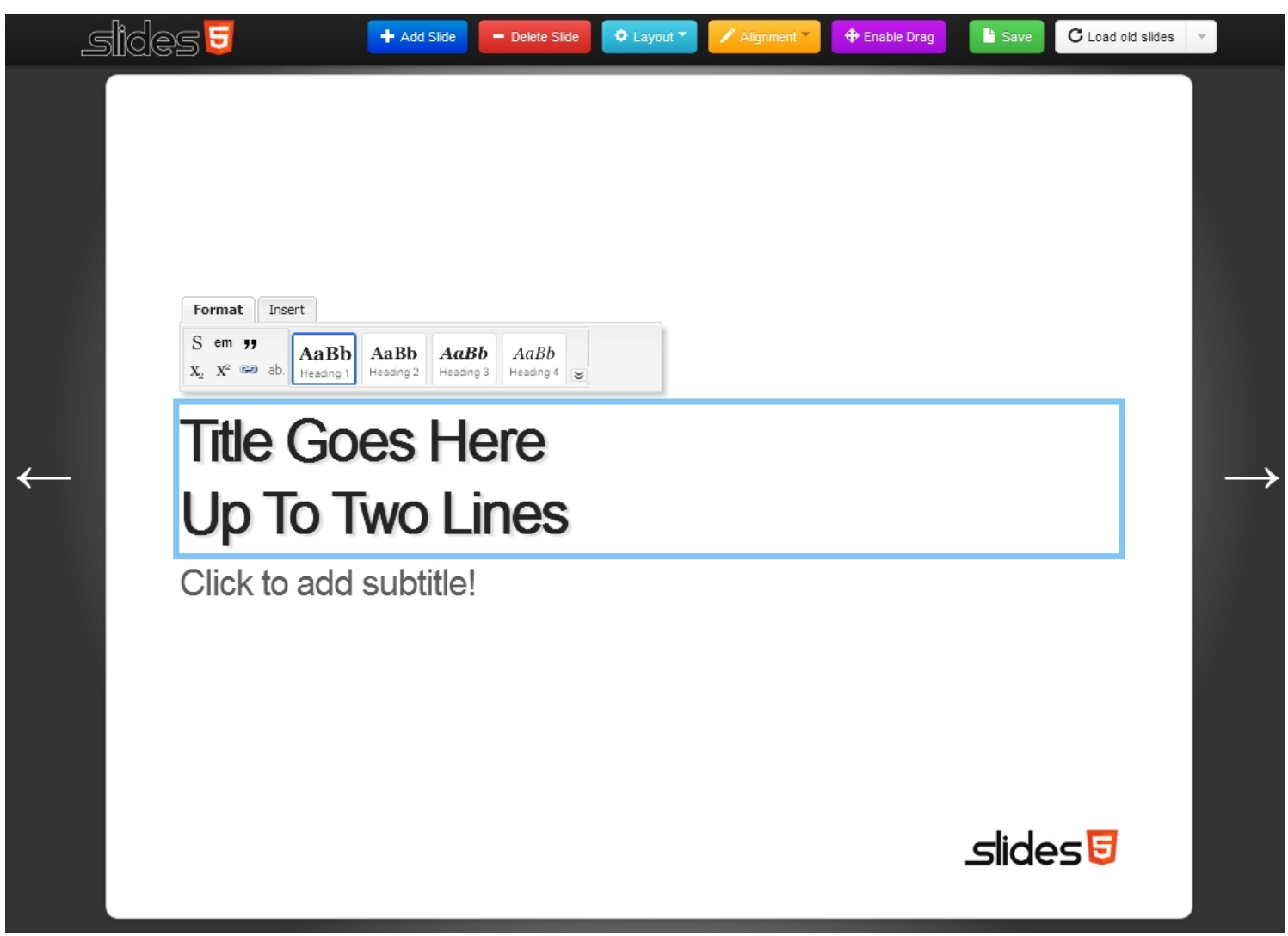

Gambar 7. Halaman pembuatan presentasi

\subsubsection{Action Panel}

Bagian ini terletak di sisi atas halaman pembuatan presentasi, berisi fungsi-fungsi yang berguna dalam membantu pengguna untuk membuat presentasi. Semua fungsi yang ada memiliki kegunaan masing-masing yang nantinya dapat dilihat pada area penyuntingan.

\subsubsection{Area Penyuntingan}

Bagian ini dapat dikatakan sebagai bagian utama dalam pembuatan presentasi. Dibantu dengan Aloha Editor, pengguna dapat memasukkan konten presentasi yang diinginkan. Layout dari area penyuntingan ini dapat dimanipulasi dengan fungsi-fungsi yang ada pada panel aksi.

\subsubsection{AreaNavigasi}

Bagian ini adalah bagian dimana pengguna dapat melakukan navigasi pada area penyuntingan, seperti berpindah maju ke slide berikut atau mundur ke slide sebelumnya. Ada dua macam cara untuk dapat melakukan navigasi, yaitu dengan melakukan klik pada area navigasi atau dengan menggunakan keyboard. Untuk navigasi dengan menggunakan keyboard, beberapa tombol yang dapat dipakai adalah sebagai berikut: (1) Next slide: dapat diakses dengan menggunakan tombol spasi, tombol page down, tombol anak panah kanan, atau tombol anak panah bawah pada keyboard. (2) Previous slide: dapat diakses dengan menggunakan tombol anak panah kiri, tombol page up, tombol backspace, atau tombol anak panah atas yang ada di keyboard.

\subsection{Halaman Unduh}

Dari halaman pembuatan presentasi, pengguna akan diarahkan ke halaman ini untuk dapat mengunduh berkas presentasi yang telah dibuat sebelumnya dalam bentuk berkas HTML. Gambar 8 adalah tampilan dari halaman unduh. Proses pengunduhan diatur supaya setelah 5 detik, kotak dialog untuk mengunduh berkas akan muncul dan pengguna dapat mulai menentukan lokasi penyimpanan berkas presentasinya. Apabila ada suatu permasalahan 
sehingga kotak dialog untuk mengunduh berkas tidak muncul dalam waktu 5 detik, maka pengguna dapat melakukan request kembali dengan melakukan klik pada tombol unduh yang juga disediakan di halaman tersebut.

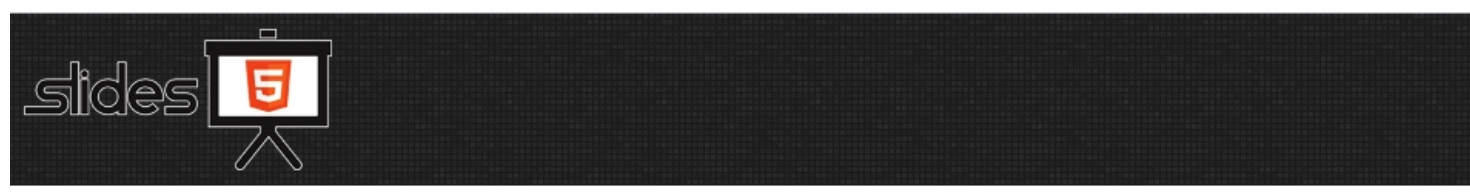

Thanks for creating presentation slides with us @Slides5! Your download will begin shortly. If you're download does not begin, you can proceed to button below.

BBC News - World

Colombia Farc hostages released

5 hours ago

The last 10 police and military hostages held by Colombia's Farc rebel group

are released after more than a decade in captivity

$\checkmark$ Colombia Farc hostages released

Police name US shooting suspect

US bounty for Pakistan militant

Deadly blaze hits Moscow market

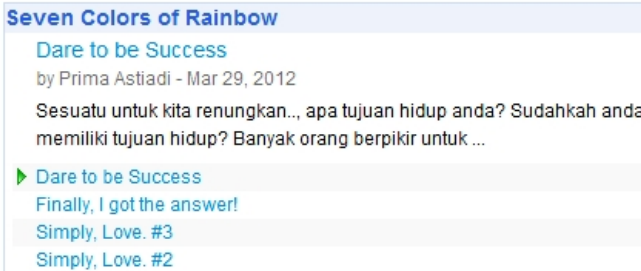

Gambar 8. Halaman unduh pada Slides5

\section{Kesimpulan dan Saran}

\subsection{Kesimpulan}

Melalui serangkaian uji coba terhadap layanan yang telah dikembangkan, didapatkan hasil sebagai berikut: (1) Slides5 sebagai layanan pembuatan presentasi berbasis web dapat membantu dalam membuat materi presentasi berbasis web dengan mudah. (2) Berkas presentasi dalam format HTML yang dapat diterima oleh mayoritas peramban web dapat menjadi solusi atas permasalahan kompatibilitas yang ditemui pada aplikasi standalone pembuatan presentasi.

\subsection{Saran}

(1) Penggunaan Aloha Editor sebagai editor pembantu cukup membebani sistem, ditunjukkan dengan lamanya page loading time yang mencapai tiga menit dengan kecepatan internet sebesar $30 \mathrm{kbps}$. Diharapkan dalam proses pengembangan berikutnya dapat menggunakan editor lain dengan performa yang lebih baik. (2) Slides5 saat ini hanya berfokus untuk menerima masukan berupa teks saja. Diharapkan dalam pengembangan berikutnya dapat ditambahkan fitur untuk menerima masukan lain seperti data gambar atau yang lainnya.

\section{Referensi}

Hogan, B.P. 2013. HTML5 and CSS3: Level Up with Today's Web Technologies, Second Editon. Dallas, TX, USA: PragmaticProgrammers.

Clark, R., Studholme, O., Murphy, C., \& Manian, D. 2012. Beginning HTML5 and CSS 3. New York, NY, USA: Apress.

David, M. 2010. HTML5 Designing Rich Internet Application. Burlington, MA, USA: Elsevier. Devlin, I. 2012. HTML5 Multimedia: Develop and Design. Berkeley, CA, USA: Peachpit.

Gilmore, W.J. 2011. Easy PHP Websites with the Zend Framework. USA: WJ Gilmore.

Goldstein, A., Lazaris, L., \& Weyl, E. 2011. HTML5 \& CSS3 for the Real World. Collingwood, VIC, Australia: SitePoint. 
126 Jurnal Buana Informatika, Volume 5, Nomor 2, Juli 2014: 115-126

Gustafson, J.M. 2013. HTML5 Web Application Development By Example: Beginner's guide. Birmingham, UK: Packt.

Powell, T.A. 2010. HTML \& CSS: The Complete Reference, Fifth Edition. New York, NY, USA: McGraw-Hill.

Robbins, J.N. 2013. HTML5 Pocket Reference, Fifth Edition. Sebastopol, CA, USA: O'Reilly.

Sanders, B. 2011. Smashing HTML5, FirstEdition. Chichester, West Sussex, UK: John Wiley \& Sons. 